\title{
GIS-based classification and mapping of forest site conditions and vegetation
}

\author{
Clasificación y mapeo en SIG de la condición y vegetación forestal
}

\author{
Vera Ryzhkova a*, Irina Danilova a \\ *Corresponding author: ${ }^{\text {a }}$ Siberian Branch, Russian Academy of Science, VN Sukachev Institute of Forest, Krasnoyarsk, \\ 660036, Russia, vera@ksc.krasn.ru
}

\begin{abstract}
SUMMARY
A method of automated classification and mapping based on a spatial analysis of a digital elevation model (Shuttle Radar Topography Mission (SRTM 90m), Landsat 5-TM imagery, and ground data was applied to classify and map forest site conditions and vegetation on a test site. The vector maps obtained reflected the test site potential environmental conditions, forest types, and regenerating vegetation age stages.
\end{abstract}

Key words: Central Siberia, site conditions and forest type mapping, geographical information system (GIS), digital elevation model (DEM), remote sensing data.

\section{RESUMEN}

Se aplicó un método de clasificación y mapeo automatizado basado en el análisis espacial de un modelo de elevación digital (Shuttle Radar Topography Mission (SRTM) 90m), imágenes satelitales Landsat 5-TM y datos de campo con el fin de clasificar y mapear la condición y vegetación forestal en sitios de prueba. Los mapas vectoriales obtenidos reflejan las condiciones ambientales potenciales del sitio de prueba, los tipos de bosque y los estados sucesionales de la regeneración de la vegetación.

Palabras clave: Siberia Central, mapeo de condiciones de sitio y del tipo de bosque, sistema de información geográfica (SIG), modelo de elevación digital (DEM), datos de sensores remotos.

\section{INTRODUCTION}

Mapping is a key tool in studying vegetation cover, particularly its spatial inventory, dynamics, and biodiversity. Nowadays, vegetation maps are successfully built and effectively updated using GIS methodologies and remote sensing data (Wondie et al. 2010, Hill et al. 2010, Bargiel and Herrmann 2011, Ohmann et al. 2011).

Our efforts have for quite a time been focused on developing GIS-based approaches to classification and mapping of forest site conditions and forest ecosystem regeneration.

The first and crucially important step to accomplishing such tasks is to choose appropriate classification principles to base map legends upon. A topogenetic (from Greek genesis - origin, i.e. based on origin in similar topographic site condition) approach developed for mountain forests of the Russian Far East (Kolesnikov 1956, Ivashkevich 1933) allows to build forest classifications that reflect regeneration dynamics of vegetation communities in different site conditions. According to the topogenetic principle, the entire diversity of vegetation communities is classified not by continuously changing outward characteristics (e.g., species composition), but by similarity of site conditions. In a given area, sites similar in topographic location and in combination of mesorelief are segregated. These are, in fact, sites similar in ecological regime.
Applying remote sensing data requires the development of methods of forest type recognition in satellite images. However, few of the characteristics behind the Russian traditional concept of forest type (Sukachev 1972) are recognizable in space imagery. For this reason, indirect characteristics, such as relief elements indicative of different site conditions are used (Bock et al. 2005, Landmann et al. 2010, Ryzhkova et al. 2011, Clerici et al. 2012).

Application of geographic information system technologies enables a minimum-human-involvement method to map forest site conditions within areas similar in a number of pre-set characteristics (e.g., climatic, orographic, edaphic, and biotic parameters) and to build a map of potential site conditions, which will serve as the basis for classifying forest communities.

\section{METHODS}

The southern part of near-Yenisei Siberia was chosen to be our test site $\left(56^{\circ}-58^{\circ} \mathrm{N}, 92^{\circ}-96^{\circ} \mathrm{E}\right)$. Topographically, this area consists of two distinct parts: West Siberiam Plain and Central Siberian Tableland. The forests of the area are markedly diverse in composition, structure and regeneration dynamics of vegetation communities comprising them. They are heavily disturbed by both natural and human factors. The major vegetation age stages occur in 
big areas covering a range of forest site conditions (Lapshina et al. 1971).

The test site forest cover was classified using the principles of the topogenetic classification (Ivashkevich 1933, Kolesnikov 1956). The main genetic unit of this classification is forest type, which is interpreted as a series of genetically linked and sequentially replaced communities developing within a certain type of site conditions. Site conditions type, which is identified based on the geological and geomorphological parameters of a given area, presents a key element of the forest type concept. The types of the major and secondary forest communities found within a given type of site conditions are grouped to constitute a vegetation regeneration series, or, in other words, a forest type (Kolesnikov 1956). The site type units and the relatively corresponding forest vegetation units are shown in table 1 .

To carry out automatized classification of a DEM-composite (elevation a.s.1., slope, and curvature) and satellite images, we used standard methodologies, such as ISODATA and MAXLIKE (Tou and Gonzalez 1974, Richards and Xiuping 2005), as well as ERDAS IMAGINE 9.2 and ESRI ArcMap 9.3 products.

Using the above principles and methods, a classification of the forest site conditions and the associated vegetation types was developed for the study area typical of plain and low-mountain southern taiga forests found along Yenisei River. To do this, we used digital elevation model (SRTM-3-DEM 2010) data to build topological transects that crossed the study area and analyzed these transects using the thematic and general geographic maps contained in the GIS database, literature information, and ground observation data.

\section{RESULTS}

An automated classification and mapping of forest site conditions and vegetation based on a spatial analysis of a DEM, satellite imagery, and ground data was developed and applied to the test site. The topographic profiles we built and landscape maps (Sochava 1977, Gudilin 1987) were used to analyze the test site geomorphological conditions and to identify sites relatively similar in topography (ratio between mesorelief forms, range of elevations a.s.1., and surface roughness) and corresponding to certain landscape types and their combinations. A preliminary number of classes for an unsupervised DEM classification was determined.

To establish the boundaries of these classes, a two-layer (elevation and slope) image was classified using ISODATA. This enabled to identify terrain roughness classes relatively similar in morphometric relief parameters (table 2) and interpret them thematically with respect to geomorphology, zonal soil types, and vegetation. Forest site conditions types were identified for each geomorphological complex (GMC) based on the ranges of slope and elevation above sea level (m a.s.1.).

As a result, a map of potential site conditions was built, which shows sites similar in topographic location, soil, and hydrological conditions, i.e. in ecological regime, the main vegetation cover control.

The most common vegetation regeneration series were determined for a range of site conditions found in each of geomorphological complexes of the test site with the help of ground data, archived and literature evidence. The vegetation regeneration series were formed from age stages grouped within each age class.

A Landsat 5-TM image was analyzed to identify land cover classes based on spectral characteristics and to interpret them as the following age or regeneration stages of forest vegetation: a) initial regeneration stages (burned and logged sites); b) young (up to 40 years old) deciduous stands; c) deciduous stands aging 40-80; (d) conifer stands 80- 120 years old approaching cutting age; and (e) mature and old conifer stand over 120 years of age.

The results of the imagery analysis were superposed on the geographic information system layer of potential forest site conditions. The information classes were analyzed and identified according to the expert classification developed by the authors. This allowed us to build vector polygonal layers reflecting the distribution of vegetation regeneration series (forest types) and stages in a range of site conditions found in the test site (figure 1).

Table 1. Relatively correspondent vegetation and site condition units.

Vegetación correspondiente relativa y unidades de condición de sitio.

Topogenetic vegetation classification units

Stand type (age stage)

Forest type (short vegetation regeneration series, a part of long-term natural succession)

Group of forest types (a long-term regeneration series, or a natural succession series)

Geomorphological complex of forest types
Forest site conditions classification units

Elementary ecotope

Forest site condition type, i.e. sites similar in slope, aspect, and hydrological regime

Group of forest site condition types - sites similar in mesorelief elements (watersheds, slopes, river valleys, depressions, etc.) and moisture regime

Geomorphological complex of forest site condition types - sites similar in mesorelief form proportions, elevation range, and roughness 
Table 2. Geomorphological complex (GMC) morphometric parameters.

Parámetros morfométricos de GMC.

\begin{tabular}{ccccccc}
\hline & \multicolumn{5}{c}{ Class parameters } \\
\hline \multirow{2}{*}{$\begin{array}{c}\text { GMC class } \\
\text { number }\end{array}$} & $\begin{array}{c}\text { Elevation } \\
\text { m a.s.1. }\end{array}$ & $\begin{array}{c}\text { Mean elevation } \\
\text { m a.s.l. }\end{array}$ & $\begin{array}{c}\text { Elevation } \mathrm{m} \\
\text { a.s.l. STD }\end{array}$ & $\begin{array}{c}\text { Slope interval, } \\
\text { deg. }\end{array}$ & $\begin{array}{c}\text { Mean slope, } \\
\text { deg. }\end{array}$ & $\begin{array}{c}\text { Slope STD, } \\
\text { deg. }\end{array}$ \\
\hline I & $184-225$ & 204.8 & 20.74 & $0.08-2.66$ & 1.37 & 1.29 \\
II & $241-273$ & 257.15 & 16.25 & $0.46-2.12$ & 1.29 & 0.83 \\
III & $203-268$ & 235.83 & 32.45 & $0.00-6.29$ & 3.13 & 3.16 \\
IV & $296-337$ & 316.4 & 20.9 & $0.57-2.95$ & 1.76 & 1.19 \\
V & $320-409$ & 364.27 & 44.51 & $1.30-7.42$ & 4.36 & 3.06 \\
VI & $158-269$ & 213.6 & 55.72 & $0.00-4.70$ & 2.19 & 2.51 \\
VII & $293-377$ & 335.1 & 41.83 & $0.75-4.97$ & 2.87 & 2.11 \\
VIII & $106-162$ & 134.1 & 28.11 & $0.15-3.23$ & 1.69 & 1.54 \\
IX & $473-561$ & 516.63 & 43.96 & $1.66-6.80$ & 4.23 & 2.57 \\
X & $208-269$ & 238.45 & 30.8 & $1.06-3.27$ & 2.16 & 1.11 \\
\hline
\end{tabular}

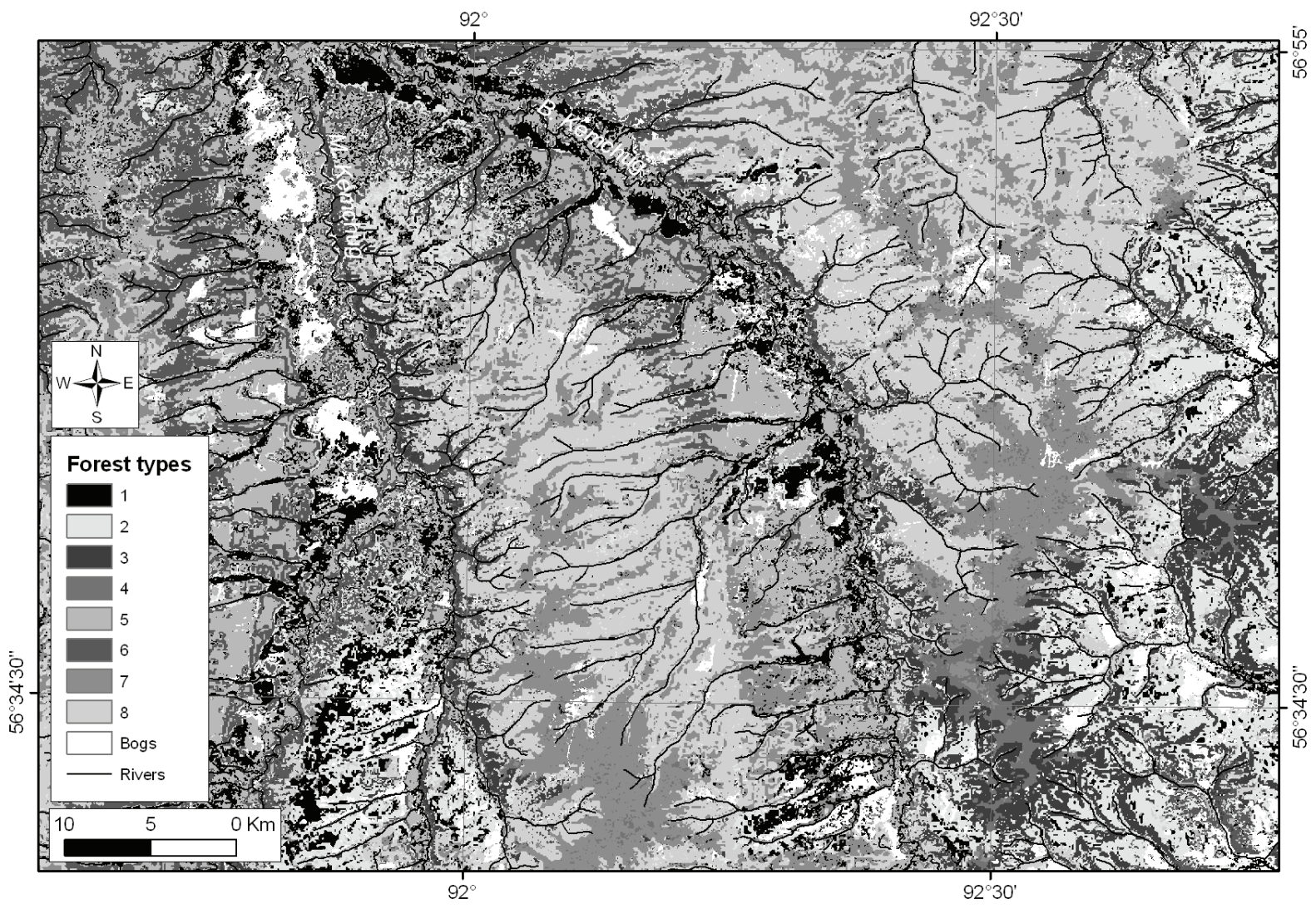

Figure 1. Fragment of the study area forest dynamics map (layer of forest types). See text for forest type description. Fragmento del área de estudio y dinámica forestal (capas de tipos de bosque). Ver texto para descripción de tipos de bosque. 
Forest types in a range of site conditions: 1 . Scots pine/ tall grass/forb stands supported by dark-colored sod forest soils and dark-grey loamy forest soils occur in watersheds and on the adjacent very soft slopes. 2. Scots pine/forb stands on sod-slightly podzolic, sod acidic forest, and grey loamy forest soils are limited to soft $\left(1-3^{\circ}\right)$ slopes. 3. Scots pine/forb/whortleberry (Vaccinium vitis-idaea) stands on sod-podzolic soils and light-grey forest loamy sand on moderately steep $\left(3-5^{\circ}\right)$ slopes. 4 . Mixed Scots pine/dark conifer/feather moss/grass stands on lightly loamy podzolic soils in convex watersheds. 5. Fir/spruce/tall grass/ forb stands supported by dark-colored sod forest, darkgrey, and double-humus-horizon moderately loamy sodpodzolic soils on flat-topped elevations and the adjacent soft slopes of an accumulative high plain. 6. Mixed fir/ spruce/grass stands on sod-podzolic and grey forest soils on an accumulative high plain slopes. 7. Mixed fir/spruce/feather moss/short grass stands on sod-podzolic loamy soils on flat watersheds and soft slopes in the low-elevated part of the mountain range $\left(1-3^{\circ}\right)$. 8. Mixed fir/spruce/ feather moss/forb stands on sod-podzolic loamy soils on various slopes in the low-elevation part of the mountain range.

\section{DISCUSSION AND CONCLUSIONS}

The genetic classification is highly promising regarding GIS-based mapping of vegetation cover dynamics. This classification covers characteristics of natural and human-caused changes in the temporal and spatial patterns of the main structural forest cover units, i.e. forest types, considers forest site conditions and all forest development stages (Kolesnikov 1956). These advantages of the classification, when taken together, are an excellent tool for predicting vegetation succession directions and rates (Ryzhkova et al. 2011).

The characteristics of two geomorphological complexes of forest site conditions with an account of geomorphology, zonal soil types, and vegetation summarizes in table 3 .

GIS technologies are very useful to compare and analyze various information layers and thus to ensure more objective identification of the links between vegetation and eco-geographic factors (Hill et al. 2010, Bargiel and Herrmann 2011, Ohmann et al. 2011).

A methodology of automated mapping of potential site conditions and forest regeneration dynamics involving a spatial analysis of multi-band satellite data, a digital elevation model, and ground measurements were developed and applied to south central Siberia. The combined use of automated methods and expert interpretation of the classes obtained allowed us to identify certain characteristics, such as forest site conditions types, forest types, and age stages of regenerating vegetation, unrecognizable in space images, but important regarding thematic mapping.

The application of the proposed approach enables to obtain vector maps showing the test site potential forest site conditions, forest types, and the regenerating vegetation age stages based on DEM (SRTM 90m) and Landsat ETM+ imagery.

\section{ACKNOWLEGMENTS}

This study was supported by Russian Foundation for Basic Research project 10-05-0094, project ZAPAS (Assessment and Monitoring of Forest Resources in the Framework of the EU-Russia Space Dialogue), project 27.32 (Basic Research Program of Presidium RAS) and Interdisciplinary project 14 .

Table 3. Forest site conditions and the corresponding forest types (forest vegetation regeneration series).

Condiciones del sitio forestal y los tipos forestales correspondientes (i.e. series de regeneración de la vegetación forestal).

\begin{tabular}{|c|c|c|c|}
\hline $\begin{array}{l}\text { GMC class } \\
\text { number }\end{array}$ & $\begin{array}{l}\text { Geomorphological complex (GMC) } \\
\text { description }\end{array}$ & $\begin{array}{l}\text { Forest site conditions types } \\
\text { based on slope range }\end{array}$ & $\begin{array}{c}\text { Forest type } \\
\text { (Kolesnikov 1956) }\end{array}$ \\
\hline III & $\begin{array}{l}\text { Elongate-elevated or rolling, elevated and ridged } \\
\text { (riverside), denudation, and denudation-erosional } \\
\text { plains (203-268 m a.s.l.) made up by light-brown and } \\
\text { yellow-brown loessed deluvial-eluvial mid-weight and } \\
\text { light pulverescent- limous clays, and, on high-to-middle } \\
\text { river terraces, by light loams and loamy sands. The } \\
\text { soils are of the dark-gray and grey forest type, leached } \\
\text { chrnozems, in places, grass sod-podzilic and podzolic. }\end{array}$ & $\begin{array}{l}0-1 \\
1-3 \\
3-5\end{array}$ & $\begin{array}{l}\text { Scots pine/herb/tall grass } \\
\text { Scots pine/herb } \\
\text { Scots pine/red } \\
\text { whortleberry/herb } \\
\text { Scots pine/herb/feather } \\
\text { moss }\end{array}$ \\
\hline $\mathrm{V}$ & $\begin{array}{l}\text { Hilly-ridged, ridged-bold-hilled dissected plateaus } \\
\text { with different slopes ( } 320-409 \mathrm{~m} \text { a.s.l.) made up by } \\
\text { proluvial and eluvial-deluvial brown and red-brown, } \\
\text { crush-stoned, heavy loams and loamy sands. The soils } \\
\text { are grass sod-podzolis (grass sod-deep podzolic), forest } \\
\text { grey, gleic. }\end{array}$ & $\begin{array}{l}0-1 \\
1-3 \\
3-5 \\
>5\end{array}$ & $\begin{array}{l}\text { Fir/spruce/grassy bog } \\
\text { Spruce/fir/small grass/ } \\
\text { feather moss } \\
\text { Spruce/fir/grass/feather } \\
\text { moss } \\
\text { Spruce/fir/feather moss }\end{array}$ \\
\hline
\end{tabular}




\section{REFERENCES}

Bargiel D, S Herrmann. 2011. Multi-Temporal Land-Cover Classification of Agricultural Areas in Two European Regions with High Resolution Spotlight TerraSAR-X Data. Remote Sensing 3: 859-877. DOI: 10.3390/rs3050859.

Bock M, P Xofisb, J Mitchleyb, G Rossnerc, M Wissenc. 2005. Object-oriented methods for habitat mapping at multiple scales - Case studies from Northern Germany and Wye Downs, UK. Journal for Nature Conservation 13:75-89.

Clerici N, C Weissteiner, F Gerard. 2012. Exploring the Use of MODIS NDVI-Based Phenology Indicators for Classifying Forest General Habitat Categories. Remote Sensing 4: 1781-1803. DOI: 10.3390/rs4061781.

Gudilin IS. 1987. The USSR Landscape Map $(1: 2,500,000)$. Moscow, Russia.

Hill R, A Wilson, M George, S Hinsley. 2010. Mapping tree species in temperate deciduous woodland using time-series multi-spectral data. Applied Vegetation Science 13: 86-99. DOI: 10.1111/j.1654-109X.2009.01053.

Ivashkevich BA. 1933. Forests of the Russian Far East and their future use. Khabarovsk, Russia. The Russian Far East OGIZ. 168 p.

Kolesnikov BP. 1956. Siberian pine forests of the Russian Far East. Moscow-Leningrad, Russia. Nauka Press. 261 p.

Landmann T, M Schramm, R Colditz, A Dietz, S Dech. 2010. Wide area wetland mapping in semi-arid Africa using 250-meter MODIS metrics and topographic variables. Remote Sensing 2: 1751-1766. DOI: 10.3390/rs2071751.
Lapshina EI. VN Gorbachev, AA Khramov. 1971. Vegetation and soils of Yenisei Mountain Chain. In Vegetation on the right bank of Yenisei River. Novosibirsk, Russia. Nauka Press. 21-66 p.

Ohmann J, M Gregory, E Henderson, H Roberts. 2011. Mapping gradients of community composition with nearest-neighbour imputation: extending plot data for landscape analysis. Journal of Vegetation Science 22: 660-676.

Ryzhkova V, I Danilova, M Korets. 2011. GIS-based mapping and estimation the current forest landscape state and dynamics. Journal of Landscape Ecology 4(1): 42-55.

Sochava VB. 1977. Landscapes of Southeastern Siberia (1:1 500000 map). Moscow, Russia.

Sukachev VN. 1972. Selected Works. Fundamentals of forest typology and biogeocenology. Vol. 1. Leningrad, Russia. Nauka Press. 418 p.

SRTM-3-DEM (Shuttle Radar Topography Mission, Digital Elevation Model). 2010. Date of Use: May 25, Available from http://www2.jpl.nasa.gov/srtm/russia.htm

Tou JT, RC Gonzalez. 1974. Pattern recognition principles. Reading, Massachusetts, USA. Addison-Wesley Publishing Company. 395 p.

Richards JA, J Xiuping. 2005. Remote sensing digital image analysis: an introduction. Basel, Switzerland. Birkhäuser. $439 \mathrm{p}$.

Wondie M, W Schneider, A Melesse, D Teketay. 2010. Spatial and Temporal Land Cover Changes in the Simen Mountains National Park, a World Heritage Site in Northwestern Ethiopia. Remote Sensing 3: 752-766.

Recibido: 24.05 .12

Aceptado: 10.10 .12 